\title{
Levantite, $\mathrm{KCa}_{3}\left(\mathrm{Al}_{2} \mathrm{Si}_{3}\right) \mathrm{O}_{11}\left(\mathrm{PO}_{4}\right)$, a new latiumite group mineral from pyrometamorphic rock of the Hatrurim Basin, Negev Desert, Israel
}

\author{
Evgeny V.Galuskin ${ }^{1 *}$, Biljana Krüger ${ }^{2}$, Irina O. Galuskina ${ }^{1}$, Hannes Krüger $^{2}$, Yevgeny \\ Vapnik $^{3}$, Anuschka Pauluhn ${ }^{4}$ and Vincent Olieric ${ }^{4}$
}

${ }^{1}$ Department of Geochemistry, Mineralogy and Petrography, Faculty of Earth Sciences, University of Silesia, Będzińska 60, 41-200 Sosnowiec, Poland

${ }^{2}$ Institute of Mineralogy and Petrography, University of Innsbruck, Innrain 52, 6020 Innsbruck, Austria

${ }^{3}$ Department of Geological and Environmental Sciences, Ben-Gurion University of the Negev, POB 653,

Beer-Sheva 84105, Israel

${ }^{4}$ Swiss Light Source, Paul Scherrer Institute, 5232 Villigen, Switzerland

*E-mail: evgeny.galuskin@us.edu.pl

\section{Abstract}

Levantite, with end-member formula $\mathrm{KCa}_{3}\left(\mathrm{Al}_{2} \mathrm{Si}_{3}\right) \mathrm{O}_{11}\left(\mathrm{PO}_{4}\right)$ is a phosphorus analogue of latiumite, $\mathrm{KCa}_{3}\left(\mathrm{Al}_{3} \mathrm{Si}_{2}\right) \mathrm{O}_{11}\left(\mathrm{SO}_{4}, \mathrm{CO}_{3}\right)$ found in gehlenite-wollastonite hornfels in the area of the Parsa Mt, Negev Desert, Israel. Levantite forms later zones on long-prismatic crystals of latiumite. Rarer homogeneous colourless levantite crystals up to $0.2 \mathrm{~mm}$ in length and with mean composition $\quad\left(\mathrm{K}_{0.94} \mathrm{Ba}_{0.01} \mathrm{Na}_{0.01} \square_{0.04}\right)_{\Sigma 1.00}\left(\mathrm{Ca}_{2.96} \mathrm{Mg}_{0.03}\right)_{\Sigma 2.99}\left\{\left(\mathrm{Si}_{2.69} \mathrm{Al}_{2.06} \mathrm{Fe}^{3+}{ }_{0.16} \mathrm{P}_{0.06}\right)_{\Sigma 4.97} \mathrm{O}_{11}\right\}$ $\left[\left(\mathrm{PO}_{4}\right)_{0.65}\left(\mathrm{SO}_{4}\right)_{0.35}\right]_{\Sigma 1.00}$ were noted. Minerals of the levantite-latiumite series are associated with gehlenite, wollastonite, clinopyroxene of the esseneite-diopside series, anorthite and Ti-bearing andradite. Levantite crystalises in space group $P 2_{1}$ with unit cell parameters $a=12.1006(9) \AA, b$ = 5.1103(4) $\AA, c=10.8252(9) \AA, \beta=107.237(8)^{\circ}, V=639.34(9) \AA^{3}, Z=2$. The structure of levantite is analogous to latiumite. It is formed by tetrahedral hybrid zweier double layers

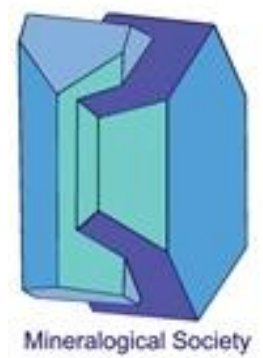

This is a 'preproof' accepted article for Mineralogical Magazine. This version may be subject to change during the production process.

DOI: $10.1180 / \mathrm{mgm} .2019 .37$ 
$\left[(\mathrm{Si}, \mathrm{Al})_{10} \mathrm{O}_{22}\right]$ connected by $\mathrm{Ca}$ atoms. Three $\mathrm{Ca}$ atoms linked to different double layers are bridged over by $\left(\mathrm{PO}_{4}\right)$ - and minor $\left(\mathrm{SO}_{4}\right)$ - groups. In cavities between two supperimposed zweier double layers reside $\mathrm{K}$-atoms. Measured micro-indentation hardness of levantite $\mathrm{VHN}_{50}=$ $580(19)$ (mean of 14) and range - 550-611 kg/mm - matching to 5 in the Mohs scale. Cleavage is good on (100). Twinning on (100) is polysynthetic or simple. Calculated density is $2.957 \mathrm{~g} \cdot \mathrm{cm}^{-}$

${ }^{3}$. Levantite is an optically negative mineral, $\alpha=1.608(2), \beta=1.618(2)$ and $\gamma=1.622(2)(\lambda=589$ $\mathrm{nm}), 2 V_{\mathrm{x}}$ (meas.): $70( \pm 5)^{\circ}, 2 V_{\mathrm{x}}$ (calc.): $64.3^{\circ}$. Dispersion: $\mathrm{r}>\mathrm{v}$, weak, orientation: $Z=b ; X^{\wedge} c=$ $22-27^{\circ}$, non-pleochroic. Minerals of the levantite-latiumite series from Israel show characteristic Raman spectra with the main bands at $994 \mathrm{~cm}^{-1}\left[v_{1}\left(\mathrm{SO}_{4}\right)^{2-}\right]$ and $945 \mathrm{~cm}^{-1}\left[v_{1}\left(\mathrm{PO}_{4}\right)^{3-}\right]$. Band intensity $v_{1}\left(\mathrm{PO}_{4}\right)^{3-} / v_{1}\left(\mathrm{SO}_{4}\right)$ ratio is well correlated with $\mathrm{P}$ and $\mathrm{S}$ contents in the investigated minerals. The following strong lines are represented in powder diffraction pattern $(d / I)$ : $3.0762(100), \quad 2.8551(96), \quad 2.9704(92), \quad 2.8573(83), \quad 2.5552(66), \quad 2.8228(48), \quad 2.8893(40)$, $3.0634(30)$.

Keywords: levantite, latiumite group, new minerals, Raman spectrum, pyrometamorphic rocks, Hatrurim Complex

\section{Introduction}

The new mineral levantite was found in gehlenite-esseneite-wollastonite hornfels at northern slope of the Har (Mountain) Parsa (N31²'29”, E35 16'45.6”) in the Negev Desert near Arad, Israel. Mt Parsa is located within the biggest field of pyrometamorphic rocks of the Hatrurim Complex known as the Hatrurim Basin (Bentor, 1960; Gross, 1977, 1984; Vapnik et al., 2007). Levantite (IMA2017-010) was approved by the Commission on New Minerals, Nomenclature and Classification (CNMNC) of the International Mineralogical Association (IMA) with the chemical formula $\mathrm{KCa}_{3} \mathrm{Al}_{2}\left(\mathrm{SiO}_{4}\right)\left(\mathrm{Si}_{2} \mathrm{O}_{7}\right)\left(\mathrm{PO}_{4}\right)$. However, as the main building element in the structure of levantite (as in the minerals of the latiumite group) is a hybrid zweier double layer $\left[(\mathrm{Si}, \mathrm{Al})_{5} \mathrm{O}_{11}\right]$, the formula should be changed to $\mathrm{KCa}_{3}\left(\mathrm{Al}_{2} \mathrm{Si}_{3}\right) \mathrm{O}_{11}\left(\mathrm{PO}_{4}\right)$. 
Pyrometamorphic rocks of the Hatrurim Complex are widely distributed along the Dead Sea Rift in the territory of Israel, Palestine and Jordan. They are represented by high-temperature rocks and products of their low-temperature alteration (Bentor, 1960; Gross, 1977, 1984; Vapnik et al., 2007; Novikov et al., 2013). Spurrite marbles, larnite rocks and gehlenite hornfels are predominant among the high-temperature rocks.

Formation of high-temperature rocks corresponding to the sanidinite facies was related to combustion processes of sedimentary protolith (Matthews and Gross, 1980; Sokol et al., 2010, 2012; Geller et al., 2012; Novikov et al., 2013). A more detailed description of the two main hypotheses on the genesis of these rocks can be found in Galuskina et al. (2014).

Levantite is a new mineral in the latiumite group, which includes also latiumite, tuscanite and queitite. Levantite $\left(P 2_{1} ; a=12.1006(9), b=5.1103(4), c=10.8252(9) \AA, \beta=107.237(8)^{\circ}\right)$ is a $\mathrm{PO}_{4}$-analog of latiumite $\left(P 2_{1}, a=12.06, b=5.08, c=10.81 \AA, \beta=106^{\circ}\right.$; Tilley and Henry, 1952; Cannillo et al., 1973). The crystal structure of latiumite was refined from the holotype sample with an empirical formula $\left(\mathrm{K}_{0.85} \square_{0.15}\right) \mathrm{Ca}_{3}\left(\mathrm{Si}_{2.15} \mathrm{Al}_{2.85}\right) \mathrm{O}_{11}\left(\mathrm{SO}_{4}\right)_{0.7}\left(\mathrm{CO}_{3}\right)_{0.3}(\mathrm{Cannillo}$ et al., 1973). Consequently, the formally approved chemical formula of latiumite is $(\mathrm{Ca}, \mathrm{K})_{4}(\mathrm{Si}, \mathrm{Al})_{5} \mathrm{O}_{11}\left(\mathrm{SO}_{4}, \mathrm{CO}_{3}\right)$ (IMA_Master_List_2018). Because of the analogy with levantite, the end-member formula of latiumite could be written as $\mathrm{KCa}_{3}\left(\mathrm{Al}_{3} \mathrm{Si}_{2}\right) \mathrm{O}_{11}\left(\mathrm{SO}_{4}\right)$.

The mineral tuscanite $\left(P 2_{1} / a, a=24.036(14), b=5.110(3), c=10.888(8) \AA, \beta=106.95^{\circ}\right)$ exhibits a related unit cell (doubled $a$ parameter) and was described with the empirical formula of $\left[\mathrm{K}_{0.88} \mathrm{Sr}_{0.04}\left(\mathrm{H}_{2} \mathrm{O}\right)_{1.08}\right]\left(\mathrm{Ca}_{5.25} \mathrm{Na}_{0.51} \mathrm{Fe}^{3+}{ }_{0.10} \mathrm{Mg}_{0.11}\right)\left(\mathrm{Si}_{6.34} \mathrm{Al}_{3.66}\right) \mathrm{O}_{22}\left(\mathrm{SO}_{4}\right)_{1.38}\left(\mathrm{CO}_{3} \mathrm{OH}\right)_{0.55}\left(\mathrm{O}_{4} \mathrm{H}_{4}\right)_{0.11}$ (Orlandi et al., 1977; Mellini et al., 1977). Accordingly, the simplified formula of tuscanite is $\mathrm{KCa}_{6}(\mathrm{Si}, \mathrm{Al})_{10} \mathrm{O}_{22}\left(\mathrm{SO}_{4}, \mathrm{CO}_{3}\right)_{2}(\mathrm{OH}) \cdot \mathrm{H}_{2} \mathrm{O}$ (IMA_Master_List_2018). Latiumite and tuscanite were found in ejected blocks of carbonate rocks within andesite tuffs (pumice-stone deposit) in the Latium and Tuscany regions, Italy (Tilley and Henry, 1952; Orlandi et al., 1977). Tuscanite and latiumite show impurities of $\mathrm{CO}_{3}$-groups substituting for $\left(\mathrm{SO}_{4}\right)^{2-}$ (Cannillo et al., 1973; Mellini et al., 1977).

Moreover, the $\mathrm{Pb}-\mathrm{Zn}$ analogue of latiumite, named queitite $\left(P 2_{1}, a=11.362, b=5.266, c\right.$ $\left.=12.655 \AA, \beta=108.16^{\circ}\right)$ is listed with the formula $\mathrm{Zn}_{2} \mathrm{~Pb}_{4}\left(\mathrm{Si}_{2} \mathrm{O}_{7}\right)\left(\mathrm{SiO}_{4}\right)\left(\mathrm{SO}_{4}\right)$ (IMA_Master_List_2018). This formula should also be rewritten as $\mathrm{PbPb}_{3}\left(\mathrm{Zn}_{2} \mathrm{Si}_{3}\right) \mathrm{O}_{11}\left(\mathrm{SO}_{4}\right)$ to feature the composition of the hybrid zweier double layers. Queitite was discovered in a $\mathrm{Pb}-\mathrm{Zn}$ ore deposit in Tsumeb, Namibia (Keller et al., 1979) and later it was found in rock dumps of the 
Pb-Zn Red Gill Mine, Caldbeck Fells, Cumbria, England (Braithwaite et al., 1989) and Horner's Vein, Leadhills, Lanarkshire, Scotland (Jackson, 1990).

Besides the above mentioned minerals, a synthetic compound $\mathrm{LaAlSiO}_{5}\left(P 2{ }_{1}{ }_{2} 2_{1}, a=\right.$ 11.0525(7) $\AA, b=5.2261(3) \AA, c=23.7049(21) \AA$ ) is known, which exhibits the same type of tetrahedral hybrid zweier double layers $\left[(\mathrm{Al}, \mathrm{Si})_{5} \mathrm{O}_{11}\right]$ (Kahlenberg and Krüger, 2004). Type material of levantite is deposited in the mineralogical collection of the Fersman Mineralogical Museum, Leninskiy pr., 18/к2, 115162 Moscow, Russia, catalogue number 4898/1.

The minerals latiumite and tuscanite are named after the regions Lazio (lat. Latium) and Tuscany, respectively. Consequently, the new mineral is named levantite after the Levant area. The Levant is an approximate historical geographical term referring to a large area in the eastern Mediterranean. The Levant includes territories of Israel, Jordan, Palestine, Lebanon, Syria, Iraq, Cyprus and parts of Turkey. In this paper we report data on the composition and structure of the new mineral levantite.

\section{Methods of investigation}

The crystal morphology and chemical composition of levantite and associated minerals were examined using optical microscopes, as well as the analytical electron scanning microscopes Philips XL30 and Phenom XL (Faculty of Earth Sciences, University of Silesia, Sosnowiec, Poland). Chemical analyses of minerals of the levantite-latiumite series and associated minerals were obtained with the help of the CAMECA SX100 microprobe analyser (Institute of Geochemistry, Mineralogy and Petrology, University of Warsaw, Warszawa, Poland) at $15 \mathrm{kV}$ and $10-20 \mathrm{nA}$ using the following lines and standards: $\mathrm{Ba} L \alpha, \mathrm{S} K \alpha$, baryte; $\mathrm{P} K \alpha$, apatite; $\mathrm{Ca} K \alpha$, wollastonite; $\mathrm{Mg} K \alpha$, $\mathrm{Si} K \alpha$, diopside; $\mathrm{Fe} K \alpha$, hematite, $\mathrm{Al} K \alpha, \mathrm{K} K \alpha$, orthoclase; $\mathrm{Ti} K \alpha$, rutile; $\mathrm{Na} K \alpha$, albite; $\mathrm{Cr} K \alpha, \mathrm{Cr}_{2} \mathrm{O}_{3} ; \mathrm{Mn} K \alpha$, rhodonite.

Raman spectra of levantite were recorded on a WITec alpha 300R Confocal Raman Microscope (Department of Earth Science, University of Silesia, Poland) equipped with an aircooled solid laser $(532 \mathrm{~nm})$ and a CCD camera operating at $-61{ }^{\circ} \mathrm{C}$. The laser radiation was coupled to a microscope through a single-mode optical fibre with a diameter of $3.5 \mu \mathrm{m}$. An air Zeiss LD EC Epiplan-Neofluan DIC-100/0.75NA objective was used. Raman scattered light was focused onto a multi-mode fibre and a monochromator with a $1800 \mathrm{~mm}^{-1}$ grating. The power of the laser at the sample position was $\sim 30 \mathrm{~mW}$. Fifteen scans with integration time of $3 \mathrm{~s}$ and a 
resolution of $1.5 \mathrm{~cm}^{-1}$ were collected and averaged. The spectrometer monochromator was calibrated using the Raman scattering line of a silicon plate $\left(520.7 \mathrm{~cm}^{-1}\right)$.

Single crystal diffraction experiments were performed at the beamline X06DA of the Swiss Light Source, Paul Scherrer Institute, Villigen, Switzerland. Data were collected using the multi-axis goniometer PRIGo (Waltersperger et al., 2015), a PILATUS 2M-F detector and radiation of $\lambda=0.70848 \AA$. The detector was set at $120 \mathrm{~mm}$ from the sample position, with a vertical offset of $67 \mathrm{~mm}$. A single $180^{\circ}$ omega-scan was employed to collect 1800 data frames in three minutes. The data collection was controlled by the DA+ software (Wojdyla et al., 2018), reduction of the data was performed with XDS (Kabsch 2010), and unit-cell parameters were refined with CrysAlis (Rigaku 2015).

\section{Geological setting and holotype sample description}

At the north-eastern slope of the Har Parsa small combs of gehlenite hornfelse are distributed in a field with larnite pseudoconglomerates (Vapnik et al., 2015). Yellow-brown hornfels usually consist of gehlenite, wollastonite, Ti-bearing andradite, larnite or flamite and contain accessory magnesioferrite and fluorapatite.

One individual specimen (number ZPP12) of gehlenite fine-grained hornfels collected in this area (spring 2015) has drawn our attention on the presence of rare amygdules, which are not characteristic for gehlenite hornfels (Fig. 1a). The rock-forming minerals of this rock are esseneite, anorthite and minerals of the latiumite-levantite series together with gehlenite, wollastonite, and Ti-bearing andradite. The latter three are typical for hornfels (Fig. 2a). Accessory minerals are celsian, baryte, magnesioferrite, and albite. Fine-grained hematite spherules are scattered throughout the rock. Amygdules are filled with zeolite-like Ca- and Ca$\mathrm{K}$-minerals $(\mathrm{Al}>\mathrm{Si})$ and ettringite, and sometimes leucite relics are noted in them (Fig. $2 b)$.

Composition of minerals of the levantite (Lvn) - latiumite (Ltm) series varies from $\operatorname{Lvn}_{70} \operatorname{Ltm}_{30}$ to $\operatorname{Ltm}_{60} \operatorname{Lvn}_{40}$ (Fig. $3 a$ ). Zoned crystals are typical. A generalized zonation looks as follows: levantite with mean composition $\left(\mathrm{K}_{0.87} \mathrm{Ca}_{0.06} \mathrm{Na}_{0.03} \mathrm{Ba}_{0.02} \square_{0.02}\right)_{\Sigma 1.00}\left(\mathrm{Ca}_{2.97} \mathrm{Mg}_{0.03}\right)_{\Sigma 3.00}$ $\left\{\left(\mathrm{Si}_{2.78} \mathrm{Al}_{2.06} \mathrm{Fe}^{3+}{ }_{0.09} \mathrm{P}_{0.01}\right)_{\Sigma 4.94} \mathrm{O}_{11}\right\}\left[\left(\mathrm{PO}_{4}\right)_{0.65}\left(\mathrm{SO}_{4}\right)_{0.34}\left(\mathrm{VO}_{4}\right)_{0.01}\right]_{\Sigma 1.00}$ forms late zones on latiumite crystals, $\left(\mathrm{K}_{0.72} \mathrm{Ca}_{0.06} \mathrm{Na}_{0.04} \mathrm{Ba}_{0.01} \square_{0.17}\right)_{\Sigma 1.00}\left(\mathrm{Ca}_{2.96} \mathrm{Mg}_{0.04}\right)_{\Sigma 3.00}\left\{\left(\mathrm{Si}_{2.66} \mathrm{Al}_{2.13} \mathrm{Fe}^{3+}{ }_{0.10} \mathrm{P}_{0.04}\right)_{\Sigma 0.93} \mathrm{O}_{11}\right\}$ $\left[\left(\mathrm{SO}_{4}\right)_{0.53}\left(\mathrm{PO}_{4}\right)_{0.47}\right]_{\Sigma 1.00}$ (Table 1, analyses 1, 2; Fig. $\left.2 a\right)$. 
Composition of rock-forming minerals of hornfels was also investigated. Clinopyroxene with mean composition $\mathrm{Ca}_{1.04} \mathrm{Fe}^{3+}{ }_{0.49} \mathrm{Mg}_{0.33} \mathrm{Al}_{0.09} \mathrm{Ti}^{4+}{ }_{0.06}\left(\mathrm{Si}_{1.29} \mathrm{Al}_{0.71}\right)_{\Sigma 2.00} \mathrm{O}_{6}$ contains about $50 \%$ of esseneite, $\left(\mathrm{CaFe}^{3+} \mathrm{AlSiO}_{6}\right)$, end-member and about $30 \%$ diopside, $\left(\mathrm{CaMgSi}_{2} \mathrm{O}_{6}\right)$, end-member (Supplemental Table S1, analysis 1). A mean composition of gehlenite is as follows: $\left(\mathrm{Ca}_{1.86} \mathrm{Na}_{0.12} \mathrm{~K}_{0.02}\right)_{\Sigma 2.00}\left(\mathrm{Al}_{0.51} \mathrm{Mg}_{0.25} \mathrm{Fe}^{3+}{ }_{0.10} \mathrm{Ca}_{0.06}\right)_{\Sigma 1.00}\left(\mathrm{Si}_{1.41} \mathrm{Al}_{0.69}\right)_{\Sigma 2.00} \mathrm{O}_{7}$. Calculation shows, that two main end-members are prevailing in gehlenite composition: gehlenite $\left(\mathrm{CaAl}(\mathrm{AlSi}) \mathrm{O}_{7}\right) \sim 50 \%$ and åkermanite $\left(\mathrm{Ca}_{2} \mathrm{MgSi}_{2} \mathrm{O}_{7}\right) \sim 25 \%$ (Supplemental Table S2, analysis 1). Garnet is represented by andradite, $\mathrm{Ca}_{3.03}\left(\mathrm{Fe}^{3+}{ }_{1.06} \mathrm{Ti}^{4+}{ }_{0.84} \mathrm{Mg}_{0.09}\right)_{\Sigma 1.99}\left(\mathrm{Si}_{2.18} \mathrm{Al}_{0.62} \mathrm{Fe}^{3+}{ }_{0.18} \mathrm{~V}^{5+}{ }_{0.01}\right)_{\Sigma 2.99} \mathrm{O}_{12}$, in which Tibearing end-members amounts to $\sim 40 \%$ (hutcheonite $\sim 30 \%$, schorlomite $\sim 10 \%$ ) (Supplemental Table S3, analysis 1). Rim zones on garnet are composed by andradite with $\mathrm{TiO}_{2}$ content close to 5 wt.\% (Supplemental Table S3, analysis 2). Minerals of the feldspar group are represented by anorthite and celsian (Supplemental Table S4). We failed to select separate grains of levantite from the ZPP12 specimen for structural investigation because of the small size of the levantitelatiumite crystals (Fig. 2).

Relatively large levantite crystals up to $0.2 \mathrm{~mm}$ were found within inhomogeneous dark zones, enriched in esseneite and hematite, in brown fine-grained esseneite-wollastonite-andraditegehlenite rock (specimen GZ15; Figs 1b,4). Fluorapatite and Fe-bearing spinel with corundum exsolution are accessory minerals of the rock. Brown rock forms separate fragments $5-10 \mathrm{~cm}^{2}$ in areas along cracks at the external part of big boulder about $50 \mathrm{~kg}$ weight found in autumn 2015 in wadi Bokek near Parsa Mt at 250-300 $\mathrm{m}$ from the place of the first finding of levantite. The boulder was composed by green fine-grained esseneite-anorthite- gehlenite-wollastonite rock belonging to the "olive unit" of melted rocks (Vapnik et al., 2007).

Levantite crystal shown in Fig. 4 was used for single-crystal X-ray diffraction, Raman and optical investigations. This crystal has relatively homogeneous composition $-\mathrm{Lvn}_{60-80} \mathrm{Ltm}_{20-40}$ (Fig. $3 a$ ), its mean composition corresponded to the empirical formula $\left(\mathrm{K}_{0.94} \mathrm{Ba}_{0.01} \mathrm{Na}_{0.01}\right.$ $\left.\square_{0.04}\right)_{\Sigma 1.00}\left(\mathrm{Ca}_{2.96} \mathrm{Mg}_{0.03}\right)_{\Sigma 2.99}\left\{\left(\mathrm{Si}_{2.69} \mathrm{Al}_{2.06} \mathrm{Fe}^{3+}{ }_{0.16} \mathrm{P}_{0.06}\right)_{\Sigma 4.97} \mathrm{O}_{11}\right\}\left[\left(\mathrm{PO}_{4}\right)_{0.65}\left(\mathrm{SO}_{4}\right)_{0.35}\right]_{\Sigma 1.00}($ Table 1, analysis 3).

Levantite is associated with clinopyroxene with composition $\mathrm{Ca}_{1.01} \mathrm{Fe}^{3+}{ }_{0.58} \mathrm{Mg}_{0.22} \mathrm{Fe}^{2+}{ }_{0.08}$ $\mathrm{Ti}^{4+}{ }_{0.06} \mathrm{Al}_{0.02} \mathrm{Cr}^{3+}{ }_{0.02}\left(\mathrm{Si}_{1.26} \mathrm{Al}_{0.74}\right)_{\Sigma 2.00} \mathrm{O}_{6}$ (Supplemental Table $\mathrm{S} 1$, analysis 2 ), in which esseneite end-member amounts to $\sim 58 \%$. Gehlenite is characterized by the mean composition $\left(\mathrm{Ca}_{1.94} \mathrm{Na}_{0.05}\right.$ $\left.\mathrm{K}_{0.03}\right)_{\Sigma 2.02}\left(\mathrm{Al}_{0.58} \mathrm{Mg}_{0.21} \mathrm{Fe}^{3+}{ }_{0.10} \mathrm{Fe}^{2+}{ }_{0.10}\right)_{\Sigma 0.99}\left(\mathrm{Si}_{1.37} \mathrm{Al}_{0.63}\right)_{\Sigma 2.00} \mathrm{O}_{7}$, where two end-members are 
prevail: gehlenite $\sim 58 \%$ and ackermanite $\sim 21 \%$ (Supplemental Table S2, analysis 2). Ti-bearing andradite, $\left(\mathrm{Ca}_{2.95} \mathrm{Mg}_{0.05}\right)_{\Sigma 3.00}\left(\mathrm{Fe}^{3+}{ }_{1.36} \mathrm{Ti}^{4+}{ }_{0.52} \mathrm{Fe}^{2+}{ }_{0.05} \mathrm{Cr}^{3+}{ }_{0.04} \mathrm{Al}_{0.03} \mathrm{Mg}_{0.01}\right)_{\Sigma 2.00}\left(\mathrm{Si}_{2.52} \mathrm{Al}_{0.47}\right.$ $\left.\mathrm{P}^{5+}{ }_{0.01}\right)_{\Sigma 3.00} \mathrm{O}_{12}$, contains the main end-memebers: andradite $\sim 68 \%$ and hutcheonite $\sim 23 \%$ (Supplemental Table S3, analysis 3).

Levantite is represented by colorless, long-prismatic crystals with vitreous luster. $\{100\}$, $\{101\},\{102\},\{10-1\},\{10-2\},\{001\}, \sim\{111\}, \sim\{010\}$ are the main simple forms. Measured microhardness $\mathrm{VHN}_{50}=580$ (mean 14); 550-611 kg/mm² (range), that coresponds to 5 on Mohs scale. A good cleavage on (100) is noted, parting is absent. Polysynthetic or simple twinning on (100) has been observed. Calculated density is $2.957 \mathrm{~g} \cdot \mathrm{cm}^{-3}$. Levantite is an optically negative mineral, $\alpha=1.608(2), \beta=1.618(2)$ and $\gamma=1.622(2)(\lambda=589 \mathrm{~nm}), 2 V_{\mathrm{x}}$ (meas.): $70( \pm 5)^{\circ}, 2 V_{\mathrm{x}}$ (calc.): $64 \cdot 3^{\circ}$. Dispersion: $\mathrm{r}>\mathrm{v}$, weak, orientation: $Z=b ; X^{\wedge} c=22-27^{\circ}$. The mineral is nonpleochroic.

\section{Raman spectroscopy of levantite}

Minerals of the latiumite-levantite series show characteristic Raman spectra (Fig. 5).

Strong bands are mainly related to vibrations in isolated $\left(\mathrm{PO}_{4}\right)^{3-}$ and $\left(\mathrm{SO}_{4}\right)^{2-}$ tetrahedra $($ Galuskin et al., 2016). Weaker bands originate from the structural units of the zweier double layers: $\left(\mathrm{SiO}_{4}\right)^{4-},\left(\mathrm{AlO}_{4}\right)^{5-}$ and $\left(\mathrm{Si}_{2} \mathrm{O}_{7}\right)^{6-}$. The main bands in the latiumite-levantite series are $\left(\mathrm{cm}^{-1}\right): 994$ $v_{1}\left(\mathrm{SO}_{4}\right) ; 945 v_{1}\left(\mathrm{PO}_{4}\right) ; 929 v_{1}\left(\mathrm{SiO}_{4}\right) ; 840 v_{1}\left(\mathrm{SiO}_{4}\right)+v_{1}\left(\mathrm{VO}_{4}\right) ; 757 v_{1}\left(\mathrm{AlO}_{4}\right) ; 651 v_{4}\left(\mathrm{PO}_{4}\right)$ and $(\mathrm{Si}-\mathrm{O}-\mathrm{Si}) ; 630 v_{4}\left(\mathrm{SO}_{4}\right) ; 501 v_{2}\left(\mathrm{SO}_{4}\right), 488 v_{2}\left(\mathrm{PO}_{4}\right) ; 428$ and $415 v_{2}\left(\mathrm{PO}_{4}\right)+v_{2}\left(\mathrm{SO}_{4}\right) ; 358$ and 350 $v_{2}\left(\mathrm{SiO}_{4}\right)+v_{2}\left(\mathrm{AlO}_{4}\right) ; 306 v(\mathrm{Ca}-\mathrm{O}) ; 97 v(\mathrm{~K}-\mathrm{O})(\mathrm{Fig} .5)$. The intensity ratio of the bands at 994 $v_{1}\left(\mathrm{SO}_{4}\right)$ and $945 v_{1}\left(\mathrm{PO}_{4}\right)$ correlates with the P/S ratio in the studied minerals (Fig. 5). The typical vibrational $\left(\mathrm{CO}_{3}\right)^{2-}$ band at $\sim 1080 \mathrm{~cm}^{-1}$ is absent (Fig. 5).

\section{Structure of levantite}

The crystal structure of levantite was refined from single crystal synchrotron diffraction data using the software Jana2006 (Petříček et al., 2014). Details of data collection and structure refinement are given in Table 2, final atomic coordinates are summarized in Table 3 and anisotropic temperature factors are given in Supplemental Table S5. Selected bond lengths are listed in Table 4 and bond valence sums are shown in Supplemental Table S6. The powder diffraction pattern was calculated from the obtained structure model (Supplemental Table S7). 
Inversion twinning was accounted for in the model and was proven to be present. Inspection of the reciprocal space revealed another type of twinning. Within layers parallel to $h 0 l$, twinning by partial merohedry could be observed (Fig. 6). Additional reflections can be seen in lines parallel to $\mathrm{a}^{*}$, except in those with $l=3 n$. This can be explained by two reciprocal lattices, which are equivalent by a 2[001] rotation. Introducing this type of twinning into the refinement significantly improves $R_{1}$ from ca. 0.05 to 0.038 . Furthermore, one-dimensional diffuse scattering along $\mathbf{a}^{*}$ proves that this type of twinning also generates a stacking-fault mechanism, e.g. is present on the nano-scale.

Tetrahedral hybrid zweier double layers, $\left[(\mathrm{Si}, \mathrm{Al})_{10} \mathrm{O}_{22}\right]$ are the main structural elements of levantite as well as of latiumite and tuscanite (Fig. 7, Cannillo et al. 1973). Potassium occurs in the cavities of these layers, whereas $\mathrm{Ca}$ - atoms and $\left(\mathrm{PO}_{4}\right) /\left(\mathrm{SO}_{4}\right)$ groups are located between them (Fig. $7 a, c$ ). In levantite, as in the case of latiumite, the apices of the tetrahedra of the double layer are pointing into one direction (-b), whereas in tuscanite they point into opposite directions (Fig. 7b, d; Cannillo et al., 1973; Mellini et al., 1977). The structures can be addressed as members of an OD (order-disorder) family as described by Merlino (2009).

In the double layer of levantite, the tetrahedra $T 2$ and $T 4$ are occupied by $\mathrm{Si}$ with mean $\mathrm{Si}$ O distances of $1.630 \AA$ and $1.625 \AA$, respectively (Table 4). In tuscanite and latiumite the corresponding tetrahedra ( $T 1$ and T4) exhibit mean Si-O distances of 1.62-1.63 А (Cannillo et al., 1973; Mellini et al., 1977; Fig. 7). Tetrahedra occupied by Al (in levantite T5 and T6) show mean Al-O distances equal to $1.751 \AA$ and $1.726 \AA$ (see Table 4), whereas in tuscanite and latiumite these tetrahedra (T2 and T5) have mean T-O distances of 1.74-1.75 (Cannillo et al., 1973; Mellini et al., 1977). In levantite the mean $T$-O distance at $T 3$ is $1.66 \AA$, which is slightly larger than at the Si-sites (T1 and T4). This may indicate that minor amounts of Al substitutes for Si on the $T 3$ site. In tuscanite and latiumite the corresponding tetrahedra (also T3) shows larger $T$-O distances of 1.636 and $1.68 \AA$, respectively, which is in agreement with higher $\mathrm{Al}$ content in latiumite compared to levantite and tuscanite (Cannillo et al., 1973; Mellini et al., 1977; Tables 1, 4). The most significant differences in the size of a tetrahderal site of levantite, tuscanite and latiumite are observed for the $T 1$-site in levantite (corresponding to the $S$-site in latiumite and tuscanite): $T 1=1.522 \AA, S=1.48 \AA$ (latiumite) and $1.47 \AA$ (tuscanite). Distances of $1.47-1.48 \AA$ at a tetrahedral site correspond to full occupation by sulfur (Cannillo et al., 1973; Mellini et al., $1977)$. At the same time a distance of $1.522 \AA$ is intermediate between the average $\mathrm{P}-\mathrm{O}(\approx 1.55 \AA)$ 
and S-O ( $\approx 1.48 \AA$ ) distance for tetrahedral coordination (Shannon, 1976). Consequently, it is arguable that the $T 1$ site in latiumite has a mixed character, and is s occupied by $\mathrm{P}$ and $\mathrm{S}$ (with predominance of $\mathrm{P}$, Table 3).

\section{Discussion}

The empirical crystal chemical formula of holotype levantite (Table 1) and its structural formula (Table 2) are $\left(\mathrm{K}_{0.94} \mathrm{Ba}_{0.01} \mathrm{Na}_{0.01} \square_{0.04}\right)_{\Sigma 1.00}\left(\mathrm{Ca}_{2.96} \mathrm{Mg}_{0.03}\right)_{\Sigma 2.99}\left\{\left(\mathrm{Si}_{2.69} \mathrm{Al}_{2.06} \mathrm{Fe}^{3+}{ }_{0.16} \mathrm{P}_{0.06}\right)_{\Sigma 4.97}\right.$ $\left.\mathrm{O}_{11}\right\}\left[\left(\mathrm{PO}_{4}\right)_{0.65}\left(\mathrm{SO}_{4}\right)_{0.35}\right]_{\Sigma 1.00}$ and $\mathrm{KCa}_{3}\left(\mathrm{Si}_{3} \mathrm{Al}_{1.876} \mathrm{Fe}_{0.124}\right) \mathrm{O}_{11}\left(\mathrm{P}_{0.6} \mathrm{~S}_{0.4}\right) \mathrm{O}_{4}$, respectively. These formulas can be easily simplified to the end-member formula $\mathrm{KCa}_{3}\left(\mathrm{Si}_{3} \mathrm{Al}_{2}\right) \mathrm{O}_{11}\left(\mathrm{PO}_{4}\right)$.

Microprobe data of latiumite-levantite series minerals plotted in different diagrams (Fig. 4) show a significant negative correlation between $\mathrm{P}$ and $\mathrm{S}\left(r^{2}=0.95\right)$, which is accompanied by negative correlation between $\mathrm{Si}$ and $\mathrm{Al}\left(r^{2}=-0.67\right)$. However, the data points of the $\mathrm{Si}-\mathrm{Al} \mathrm{plot}$ exhibits some scatter within 0.2 pfu. Further correlations are visible: 1) negative between $\mathrm{K}$ and vacancies $\left.\left(r^{2}=-0.86\right), 2\right)$ low positive between $\mathrm{P}$ and $\left.\mathrm{Si}\left(r^{2}=0.22\right), 3\right)$ positive between $\mathrm{S}$ and vacancies+Al-2 (Al at T3 site) $\left(r^{2}=0.56\right)$ and 4) positive between $\mathrm{S}$ and $\mathrm{Na}\left(r^{2}=0.46\right)$ (Fig. 4). These correlations indicate that three isomorphic schemes of heterovalent isomorphic substitutions exists, compensating the substitution of sulphur for phosphorus: 1$):\left(\mathrm{SiO}_{4}\right)^{4-}+$ $\left.\left(\mathrm{PO}_{4}\right)^{3-} \rightarrow\left(\mathrm{AlO}_{4}\right)^{5-}+\left(\mathrm{SO}_{4}\right)^{2-} ; 2\right): \mathrm{K}^{+}+\left(\mathrm{PO}_{4}\right)^{3-} \rightarrow \square+\left(\mathrm{SO}_{4}\right)^{2-} ;$ and 3): $\mathrm{Ca}^{2+}+\left(\mathrm{PO}_{4}\right)^{3-} \rightarrow \mathrm{Na}^{+}+$ $\left(\mathrm{SO}_{4}\right)^{2-}$. These substitutions lead to the three $\mathrm{SO}_{4}$-bearing end-members: $\mathrm{KCa}_{3}\left(\mathrm{Si}_{2} \mathrm{Al}_{3}\right) \mathrm{O}_{11}\left(\mathrm{SO}_{4}\right)$ (latiumite), $\square \mathrm{Ca}_{3}\left(\mathrm{Si}_{3} \mathrm{Al}_{2}\right) \mathrm{O}_{11}\left(\mathrm{SO}_{4}\right)$ (K-free tuscanite at $\square=\mathrm{H}_{2} \mathrm{O}$ ) and hypothetical $\mathrm{KCa}_{2} \mathrm{Na}\left(\mathrm{Si}_{3} \mathrm{Al}_{2}\right) \mathrm{O}_{11}\left(\mathrm{SO}_{4}\right)$.

Levantite from pyrometamorphic rocks of the Hatrurim Complex always contains $\left(\mathrm{SO}_{4}\right)^{2-}$, which substitutes for $\left(\mathrm{PO}_{4}\right)^{3-}$. The minimal S-content does not decrease below 0.2 apfu (Tables 1; Fig. 3). Microprobe analyses and Raman spectroscopy (Fig. 5) show that $\mathrm{CO}_{3}$ groups (being characteristic component in latiumite and tuscanite) are absent in $\mathrm{PO}_{4}$-bearing minerals of the latiumite-levantite series from pyrometamorphic rocks of the Hatrurim Complex.

The rocks addressed as hornfels rather belong to melted (partially or fully) rocks of the „olive unit” (Vapnik et al., 2007) as indicated by their mineral composition and presence of 
amygdaloidal texture (Fig. 1a). Levantite crystals occur as inclusions in esseneite and Ti-bearing andradite and in turn contain inclusions of anorthite and gehlenite crystals.

Levantite crystallizes from melt enriched in $\mathrm{K}, \mathrm{P}$ and $\mathrm{S}$. The temperature of its formation is close to what has been determined for paralava of the "olive unit" $\sim 1250^{\circ} \mathrm{C}$ (Vapnik et al., 2007). High temperature and low pressure close to atmospheric explain the absence of $\mathrm{CO}_{3}$ groups in levantite. Latiumite and tuscanite from Italian volcanites crystallized at lower temperature $\left(<1050^{\circ} \mathrm{C}\right)$ and relatively higher pressure involving $\mathrm{CO}_{2}-\mathrm{H}_{2} \mathrm{O}-\mathrm{S}-\mathrm{F}$ fluids were liberated by magma-wall rock reactions and from ultrapotassic magma (Peccerillo et al., 2010).

Acknowledgements: The authors thank Igor Pekov, Peter Leverett and anonymous reviewer for their careful review that improved the manuscript. The investigations were partially supported by the National Science Centre (NCN) of Poland, grant no. 2016/23/B/ST10/00869. HK acknowledges the assistance of K. Zöll during the data collection at the SLS.

\section{References}

Bentor Y.K. (editor) (1960) Israel. In: Lexique Stratigraphique International, Asie, Vol. III, (10.2). Centre national de la recherche scientifique, Paris.

Braithwaite R.S.W., Cooper M.P. and Hart A.D. (1989) Queitite, a mineral new to Britain, from the Caldbeck Fells,Cumbria. Mineralogical Magazine, 53, 508-509.

Cannillo E., Dal Negro A. and Rossi G. (1973) The crystal structure of latiumite, a new type of sheet silicate. American Mineralogist, 58, 466-470.

Downs T.R., Bartelmehs K.L., Gibbs G.V. and Boisen Jr M.B. (1993) Interactive software for calculating and displaying X-ray or neutron powder diffractometer patterns of crystalline materials. American Mineralogist, 78, 1104-1107.

Galuskin E.V., Galuskina I.O., Gfeller F. Krüger B., Kusz J., Vapnik Ye., Dulski M. and Dzierżanowski P. (2016) Silicocarnotite, $\mathrm{Ca}_{5}\left[\left(\mathrm{SiO}_{4}\right)\left(\mathrm{PO}_{4}\right)\right]\left(\mathrm{PO}_{4}\right)$, a new 'old' mineral from the Negev Desert, Israel, and the ternesite-silicocarnotite solid solution: indicators of high-temperature alteration of pyrometamorphic rocks of the Hatrurim Complex, Southern Levant. European Journal of Mineralogy, 28, 105-123 
Galuskina I.O., Vapnik Ye., Lazic B., Armbruster T., Murashko M. and Galuskin E.V. (2014) Harmunite $\mathrm{CaFe}_{2} \mathrm{O}_{4}-\mathrm{a}$ new mineral from the Jabel Harmun, West Bank, Palestinian Autonomy, Israel. American Mineralogist, 99, 965-975.

Geller Y.I., Burg A., Halicz L. and Kolodny Y. (2012) System closure during the combustion metamorphic "Mottled Zone" event, Israel. Chemical Geology, 334, 25-36.

Gross S. (1977) The mineralogy of the Hatrurim Formation, Israel. Geological Survey of Israel Bulletin, 70, 1-80.

Jackson B. (1990) Queitite, $\left[\mathrm{Pb}_{4} \mathrm{Zn}_{2}\left(\mathrm{SO}_{4}\right)\left(\mathrm{SiO}_{4}\right)\left(\mathrm{Si}_{2} \mathrm{O}_{7}\right)\right]$, is an extremely rare mineral. This is the first recorded Scottish occurrence and only the third world-wide. Scottish Journal of Geology, 26, 57-58.

Kabsch W. (2019) XDS. Acta Crystallographica, D66,125-132

Kahlenberg V. and Krüger H. (2004) $\mathrm{LaAlSiO}_{5}$ and apatite-type $\mathrm{La}_{9.71}\left(\mathrm{Si}_{0.81} \mathrm{Al}_{0.19} \mathrm{O}_{4}\right)_{6} \mathrm{O}_{2}$ - the crystal structures of two synthetic lanthanum alumosilicates. Solid State Sciences, 6, 553560.

Keller P., Dunn P.J. and Hess H. (1979) Queitite, $\mathrm{Pb}_{4} \mathrm{Zn}_{2}\left[\mathrm{SO}_{4}\left|\mathrm{SiO}_{4}\right| \mathrm{Si}_{2} \mathrm{O}_{7}\right]$, a new mineral from Tsumeb, South West Africa. Neues Jahrbuch für Mineralogie Mon., 1979, 203-209.

Matthews A. and Gross S. (1980): Petrologic evolution of the Mottled Zone (Hatrurim) metamorphic complex of Israel. Israel Journal of Earth Sciences, 29, 93-106.

Mellini M., Merlino S. and Rossi G. (1977) The crystal structure of tuscanite. American Mineralogist, 62,1114-1120.

Merlino S. (2009) OD approach to polytypism: examples, problems, indications. Zeitschrift für Kristallographie, 224, 251-260.

Novikov I., Vapnik Ye. and Safonova I. (2013) Mud volcano origin of the Mottled Zone, South Levant. Geoscience Frontiers, 4, 597-619.

Orlandi P., Leoni L., Mellini M. and Merlino S. (1977) Tuscanite, a new mineral related to latiumite. American Mineralogist, 62, 1110-1113.

Peccerillo A., Federico M., Barbieri M., Brilli M. and Wu T.V. (2010) Interaction between ultrapotassic magmas and carbonate rocks:Evidence from geochemical and isotopic ( $\mathrm{Sr}$, $\mathrm{Nd}, \mathrm{O})$ compositions of granular lithic clasts from the Alban Hills Volcano, Central Italy. 
Geochimica et Cosmochimica Acta, 74, 2999-3022.

Petrríček V., Dušek M. and Palatinus L. (2014) Crystallographic Computing System JANA2006:

General features. Zeitschrift für Kristallographie, 229, 345-352.

Rigaku Oxford Diffraction (2015) CrysAlisPro Software system, version 1.171.38.43, Rigaku Corporation.

Sokol E., Novikov I., Zateeva S., Vapnik Ye., Shagam R. and Kozmenko O. (2010): Combustion metamorphism in the Nabi Musa dome: New implications for a mud volcanic origin of the Mottled Zone, Dead Sea area. Basin Research, 22, 414-438.

Sokol E.V., Kozmenko O.A., Kokh S.N. and Vapnik Ye. (2012) Gas reservoirs in the Dead Sea area: evidence from chemistry of combustion metamorphic rocks in Nabi Musa fossil mud volcano. Russian Geology and Geophysics, 53, 745-762.

Tilley C.E. and Henry N.F.M (1953) Latiumite (sulphatic potassium-calcium-aluminum silicate), a new mineral from Albano, Latium, Italy. Mineralogical Magazine, 30, 39-45

Vapnik Y., Sharygin V.V., Sokol E.V. and Shagam R. (2007) Paralavas in a combustion metamorphic complex: Hatrurim Basin, Israel. Reviews in Engineering Geology,18, 1-21.

Vapnik Ye., Galuskina I., Palchik V., Sokol E.V., Galuskin E., Lindsley-Griffin N. and Stracher, G.B. (2015) Stone-Tool Workshops of the Hatrurim Basin, Israel: Mineralogy, Geochemistry, and Rock Mechanics of Lithic Industrial Materials. In Coal and Peat Fires: A Global Perspective, Eds: G. B. Stracher, A. Prakash and E.V. Sokol., 282-315. Waltersperger S., Olieric V., Pradervand C., Glettig W., Salathe M., Fuchs M.R., Curtin A., Wang X., Ebner S., Panepucci E., Weinert T., Schulze-Briese C. and Wang M (2015) PRIGo: a new multi-axis goniometer for macromolecular crystallography. Journal of Synchrotron Radiation, 22, 895-900.

Wojdyla J.A., Kaminski J.W., Panepucci E., Ebner S., Wang X., Gabadinho J. and Wang M (2018) DA+ data acquisition and analysis software at the Swiss Light Source macromolecular crystallography beamlines. Journal of Synchrotron Radiation, 25, 293303. 
Table 1. Composition of latiumite-levantite series minerals from Har Parsa, Negev Desert.

\begin{tabular}{|c|c|c|c|c|c|c|c|c|c|}
\hline & \multicolumn{3}{|c|}{1} & \multicolumn{3}{|c|}{2} & \\
\hline & \multicolumn{6}{|c|}{ ZPP12 } & \multirow{2}{*}{\multicolumn{3}{|c|}{$\begin{array}{c}\text { GZ15 } \\
\text { levantite }\end{array}$}} \\
\hline & levar & ntite $(r$ & im and top) & & tiumite & (core) & & & \\
\hline \multirow[t]{2}{*}{$n$} & 11 & & & 17 & & & 27 & & \\
\hline & wt.\% & S.D. & Range & wt.\% & S.D. & Range & wt.\% & S.D. & Range \\
\hline $\mathrm{SO}_{3}$ & 4.81 & 0.55 & $4.19-5.62$ & 7.65 & 0.96 & $5.48-8.64$ & 4.94 & 0.61 & $3.54-5.88$ \\
\hline $\mathrm{V}_{2} \mathrm{O}_{5}$ & 0.09 & 0.04 & $0.02-0.16$ & n.d. & & & n.d. & & \\
\hline $\mathrm{P}_{2} \mathrm{O}_{5}$ & 8.12 & 0.60 & $6.75-8.65$ & 6.50 & 0.83 & $5.47-8.33$ & 8.86 & 0.47 & $8.00-10.21$ \\
\hline $\mathrm{SiO}_{2}$ & 29.05 & 0.14 & $28.84-29.25$ & 28.65 & 0.37 & 27.96-29.93 & 28.45 & 0.35 & $27.79-29.06$ \\
\hline $\mathrm{Fe}_{2} \mathrm{O}_{3}$ & 1.24 & 0.09 & $1.09-1.38$ & 1.47 & 0.10 & $1.28-1.64$ & 2.03 & 0.13 & $1.76-2.38$ \\
\hline $\mathrm{Al}_{2} \mathrm{O}_{3}$ & 18.28 & 0.30 & $17.93-18.79$ & 19.49 & 0.41 & $18.89-20.25$ & 18.45 & 0.28 & $18.00-18.99$ \\
\hline $\mathrm{BaO}$ & 0.44 & 0.11 & $0.35-0.72$ & 0.23 & 0.20 & $0-0.84$ & 0.19 & 0.03 & $0.13-0.26$ \\
\hline $\mathrm{CaO}$ & 29.52 & 0.16 & 29.34-29.90 & 30.34 & 0.28 & $29.96-31.16$ & 29.15 & 0.19 & $28.87-29.67$ \\
\hline $\mathrm{MgO}$ & 0.22 & 0.05 & $0.19-0.34$ & 0.29 & 0.04 & $0.24-0.41$ & 0.18 & 0.02 & $0.13-0.23$ \\
\hline $\mathrm{K}_{2} \mathrm{O}$ & 7.12 & 0.13 & 6.95-7.39 & 6.06 & 0.51 & $5.23-6.94$ & 7.76 & 0.18 & 7.04-7.97 \\
\hline $\mathrm{Na}_{2} \mathrm{O}$ & 0.16 & 0.02 & $0.13-0.19$ & 0.21 & 0.06 & $0.09-0.29$ & 0.05 & 0.02 & $0.01-0.10$ \\
\hline Total & 99.06 & & & 100.88 & & & 100.06 & & \\
\hline \multicolumn{10}{|c|}{ Atoms per formula unit } \\
\hline $\mathrm{K}$ & 0.87 & & & 0.72 & & & 0.94 & & \\
\hline $\mathrm{Ba}$ & 0.02 & & & 0.01 & & & 0.01 & & \\
\hline $\mathrm{Na}$ & 0.03 & & & 0.04 & & & 0.01 & & \\
\hline $\mathrm{Ca}$ & 0.06 & & & 0.06 & & & & & \\
\hline$\sum A$ & 0.98 & & & 0.83 & & & 0.96 & & \\
\hline $\mathrm{Ca}$ & 2.97 & & & 2.96 & & & 2.96 & & \\
\hline $\mathrm{Mg}$ & 0.03 & & & 0.04 & & & 0.03 & & \\
\hline$\Sigma B$ & 3.00 & & & 3.00 & & & 2.99 & & \\
\hline $\mathrm{Si}$ & 2.78 & & & 2.66 & & & 2.69 & & \\
\hline $\mathrm{Al}$ & 2.06 & & & 2.13 & & & 2.06 & & \\
\hline $\mathrm{Fe}^{3+}$ & 0.09 & & & 0.10 & & & 0.16 & & \\
\hline$P$ & 0.01 & & & 0.04 & & & 0.06 & & \\
\hline$\Sigma T$ & 4.94 & & & 4.93 & & & 4.97 & & \\
\hline$P$ & 0.65 & & & 0.47 & & & 0.65 & & \\
\hline$S^{6+}$ & 0.34 & & & 0.53 & & & 0.35 & & \\
\hline $\mathrm{V}^{\mathrm{b}+}$ & 0.01 & & & & & & & & \\
\hline$\sum T^{1}$ & 1.00 & & & 1.00 & & & 1.00 & & \\
\hline
\end{tabular}


Table 2. Crystal data, X-ray measurement and refinement parameters for levantite

\begin{tabular}{|c|c|}
\hline $\begin{array}{l}\text { Crystal data } \\
\text { Chemical formula (from X-ray data) } \\
\text { Unit cell dimensions }(\AA)\end{array}$ & $\begin{array}{l}\mathrm{KCa}_{3} \mathrm{Al}_{1.876} \mathrm{Fe}_{0.124} \mathrm{Si}_{3} \mathrm{P}_{0.6} \mathrm{~S}_{0.4} \mathrm{O}_{15} \\
a=12.1006(9) \AA, \\
c=10.8252(9) \AA=5.1103(4) \AA\end{array}$ \\
\hline $\begin{array}{l}\text { Space group } \\
\text { Volume }\left(\AA^{3}\right) \\
\text { Crystal system } \\
\text { Z } \\
\text { Calculated density }\left(\mathrm{g} \mathrm{cm}^{-3}\right)\end{array}$ & $\begin{array}{l}P 21 \text { (No.4) } \\
639.34(9) \AA^{3} \\
\text { monoclinic } \\
2 \\
2.974 \mathrm{~g} / \mathrm{cm}^{3}\end{array}$ \\
\hline Data collection & \\
\hline $\begin{array}{l}\text { Crystal size }(\mathrm{mm}) \\
\text { Diffractometer }\end{array}$ & $\begin{array}{l}0.05 \times 0.04 \times 0.026 \\
\text { beamline X06DA, Swiss Light Source } \\
\text { multi-axis goniometer PRIGo } \\
\text { PILATUS } 2 \mathrm{M}-\mathrm{F} \text { detector }\end{array}$ \\
\hline X-ray radiation, wavelength $(\AA)$ & 0.7085 \\
\hline Max. $\theta^{\circ}$-range & $31.94^{\circ}$ \\
\hline $\begin{array}{l}\text { Min. } \theta^{\circ} \text {-range } \\
\text { Index ranges }\end{array}$ & $\begin{array}{l}1.76^{\circ} \\
-17 \leq h \leq 9,-6 \leq k \leq 6,-15 \leq l \leq 15\end{array}$ \\
\hline $\begin{array}{l}\text { No. of measured reflections } \\
\text { No. of unique reflections } \\
\text { No. of observed reflections } \\
(I>3 \sigma(I))\end{array}$ & $\begin{array}{l}3567 \\
2793 \\
2780\end{array}$ \\
\hline $\begin{array}{l}\text { Refinement } \\
\text { No. of parameters used } \\
\text { refinement } \\
R_{\text {int }} \\
R_{\sigma} \\
R_{1}, I>3 \sigma(I) \\
R_{1} \text { all Data } \\
w R 2 \text { on }(F 2) \\
\text { GooF } \\
\Delta \rho \min \left(-e \AA^{-3}\right) \\
\Delta \rho \text { max }\left(e \AA^{-3}\right) \\
\text { weighting details }\end{array}$ & $\begin{array}{l}0.0448 \\
0.0683 \\
0.0377 \\
0.0378 \\
0.0593 \\
1.66 \\
0.56 \text { close to } \mathrm{Ca} 2 \\
-0.86 \text { close to } \mathrm{Ca} 1 \\
\mathrm{~W}=1 /\left(\sigma^{2}(\mathrm{~F})+0.0001 \mathrm{~F}^{2}\right)\end{array}$ \\
\hline
\end{tabular}


Table 3. Atomic coordinates and equivalent isotropic displacement parameters $\left(\AA^{2}\right)$ for levantite.

\begin{tabular}{lclllcl}
\hline Site & Atom & \multicolumn{1}{c}{$x / a$} & \multicolumn{1}{c}{$y / b$} & \multicolumn{1}{c}{$z / c$} & Ueq & Occ. \\
\hline K1 & $\mathrm{K}$ & $0.42181(8)$ & $0.7548(2)$ & $0.72508(9)$ & $0.0278(3)$ & \\
Ca1 & $\mathrm{Ca}$ & $0.11022(5)$ & $0.74995(19)$ & $0.81093(7)$ & $0.0129(2)$ & \\
$\mathrm{Ca} 2$ & $\mathrm{Ca}$ & $0.80274(5)$ & $0.7565(2)$ & $0.85996(6)$ & $0.0152(2)$ & \\
$\mathrm{Ca3}$ & $\mathrm{Ca}$ & $0.88533(5)$ & $0.26803(17)$ & $0.55047(6)$ & $0.0121(2)$ & \\
T1 & $\mathrm{P}$ & $0.96279(6)$ & $0.2250(2)$ & $0.85790(8)$ & $0.0106(2)$ & $0.6^{*}$ \\
& $\mathrm{~S}$ & $0.96279(6)$ & $0.2250(2)$ & $0.85790(8)$ & $0.0106(2)$ & $0.4^{*}$ \\
$T 2$ & $\mathrm{Si}$ & $0.62164(7)$ & $0.2636(2)$ & $0.92850(8)$ & $0.0081(2)$ & \\
T3 & $\mathrm{Si}$ & $0.65574(7)$ & $0.7538(2)$ & $0.52279(8)$ & $0.0086(2)$ & \\
T4 & $\mathrm{Si}$ & $0.17725(7)$ & $0.3010(2)$ & $0.64353(8)$ & $0.0087(3)$ & \\
T5 & $\mathrm{Al}$ & $0.61754(7)$ & $0.2546(2)$ & $0.64998(8)$ & $0.0087(3)$ & $0.930(4)$ \\
& $\mathrm{Fe}$ & $0.61754(7)$ & $0.2546(2)$ & $0.64998(8)$ & $0.0087(3)$ & $0.070(4)$ \\
T6 & $\mathrm{Al}$ & $0.34657(7)$ & $0.2643(2)$ & $0.91640(8)$ & $0.0087(3)$ & $0.946(4)$ \\
& $\mathrm{Fe}$ & $0.34657(7)$ & $0.2643(2)$ & $0.91640(8)$ & $0.0087(3)$ & $0.054(4)$ \\
O1 & $\mathrm{O}$ & $0.31349(19)$ & $0.9364(6)$ & $0.9443(2)$ & $0.0123(7)$ & \\
O2 & $\mathrm{O}$ & $0.48299(19)$ & $0.2852(7)$ & $0.8950(2)$ & $0.0160(8)$ & \\
O3 & $\mathrm{O}$ & $0.6602(2)$ & $0.9553(6)$ & $0.9497(2)$ & $0.0119(7)$ & \\
O4 & $\mathrm{O}$ & $0.65966(20)$ & $0.3833(6)$ & $0.8066(3)$ & $0.0136(7)$ & \\
O5 & $\mathrm{O}$ & $0.6580(2)$ & $0.9236(6)$ & $0.6549(3)$ & $0.0153(8)$ & \\
O6 & $\mathrm{O}$ & $0.4691(2)$ & $0.2854(7)$ & $0.5888(2)$ & $0.0179(8)$ & \\
O7 & $\mathrm{O}$ & $0.6893(2)$ & $0.4431(6)$ & $0.5599(3)$ & $0.0158(8)$ & \\
O8 & $\mathrm{O}$ & $0.7565(2)$ & $0.8887(6)$ & $0.4650(2)$ & $0.0121(7)$ & \\
O9 & $\mathrm{O}$ & $0.06088(19)$ & $0.4722(6)$ & $0.6017(2)$ & $0.0126(7)$ & \\
O10 & $\mathrm{O}$ & $0.1681(2)$ & $0.9900(6)$ & $0.6487(2)$ & $0.0162(8)$ & \\
O11 & $\mathrm{O}$ & $0.25498(19)$ & $0.4209(6)$ & $0.7816(2)$ & $0.0135(7)$ & \\
O12 & $\mathrm{O}$ & $0.0931(2)$ & $0.1949(7)$ & $0.9160(3)$ & $0.0199(9)$ & \\
O13 & $\mathrm{O}$ & $0.8966(2)$ & $0.1797(7)$ & $0.9541(3)$ & $0.0198(9)$ & \\
O14 & $\mathrm{O}$ & $0.9324(2)$ & $0.4878(6)$ & $0.7920(3)$ & $0.0167(8)$ & \\
O15 & $\mathrm{O}$ & $0.9248(2)$ & $1.0150(6)$ & $0.7514(3)$ & $0.0156(8)$ & \\
P/S ratio at $T 1$ fixed according to results of chemical analyses; Occ. occupancy
\end{tabular}


Table 4. Selected interatomic distances $(\AA ̊)$ for levantite

\begin{tabular}{|c|c|c|c|c|c|}
\hline atom- & atom & distance & atom- & atom & distance \\
\hline \multirow[t]{11}{*}{$K 1$} & 011 & $2.845(3)$ & $T 1$ & 013 & $1.508(3)$ \\
\hline & 06 & $2.960(4)$ & & 014 & $1.514(3)$ \\
\hline & 02 & $2.981(3)$ & & 012 & $1.522(3)$ \\
\hline & 08 & 3.124(3) & & 015 & $1.542(3)$ \\
\hline & 07 & $3.130(3)$ & & mean & 1.522 \\
\hline & 010 & $3.170(3)$ & $T 2$ & 02 & $1.612(2)$ \\
\hline & 01 & $3.171(3)$ & & 01 & $1.628(3)$ \\
\hline & 06 & $3.218(4)$ & & O4 & $1.639(3)$ \\
\hline & 02 & $3.236(3)$ & & 03 & $1.640(3)$ \\
\hline & 05 & $3.282(3)$ & & mean & 1.630 \\
\hline & mean & 3.112 & $T 3$ & 06 & $1.639(2)$ \\
\hline \multirow[t]{9}{*}{ Ca1 } & 010 & $2.410(3)$ & & 07 & $1.659(3)$ \\
\hline & 014 & $2.491(3)$ & & 05 & 1.667(3) \\
\hline & 011 & $2.515(3)$ & & 08 & $1.674(3)$ \\
\hline & 015 & $2.535(3)$ & & & 1.660 \\
\hline & 012 & $2.578(4)$ & T4 & 010 & $1.595(3)$ \\
\hline & 09 & $2.589(3)$ & & 09 & $1.605(3)$ \\
\hline & 013 & $2.594(3)$ & & 011 & $1.632(3)$ \\
\hline & 01 & $2.634(2)$ & & 08 & $1.669(3)$ \\
\hline & mean & 2.543 & & mean & 1.625 \\
\hline \multirow[t]{8}{*}{ Ca2 } & 014 & $2.361(3)$ & 15 & 06 & $1.728(2)$ \\
\hline & 012 & $2.400(3)$ & & 04 & $1.748(3)$ \\
\hline & O3 & $2.438(3)$ & & 05 & $1.757(3)$ \\
\hline & 013 & $2.514(3)$ & & 07 & $1.770(3)$ \\
\hline & 015 & $2.517(3)$ & & mean & 1.751 \\
\hline & 04 & $2.525(3)$ & $T 6$ & 02 & $1.737(3)$ \\
\hline & 05 & $2.534(3)$ & & 011 & $1.743(3)$ \\
\hline & mean & 2.470 & & 01 & $1.770(3)$ \\
\hline \multirow[t]{8}{*}{ Ca3 } & 09 & $2.283(3)$ & & 03 & $1.770(3)$ \\
\hline & 010 & $2.351(3)$ & & mean & 1.726 \\
\hline & 015 & $2.452(3)$ & & & \\
\hline & 09 & $2.461(3)$ & & & \\
\hline & 08 & 2.488(3) & & & \\
\hline & 07 & $2.566(3)$ & & & \\
\hline & 014 & $2.746(3)$ & & & \\
\hline & mean & 2.478 & & & \\
\hline
\end{tabular}



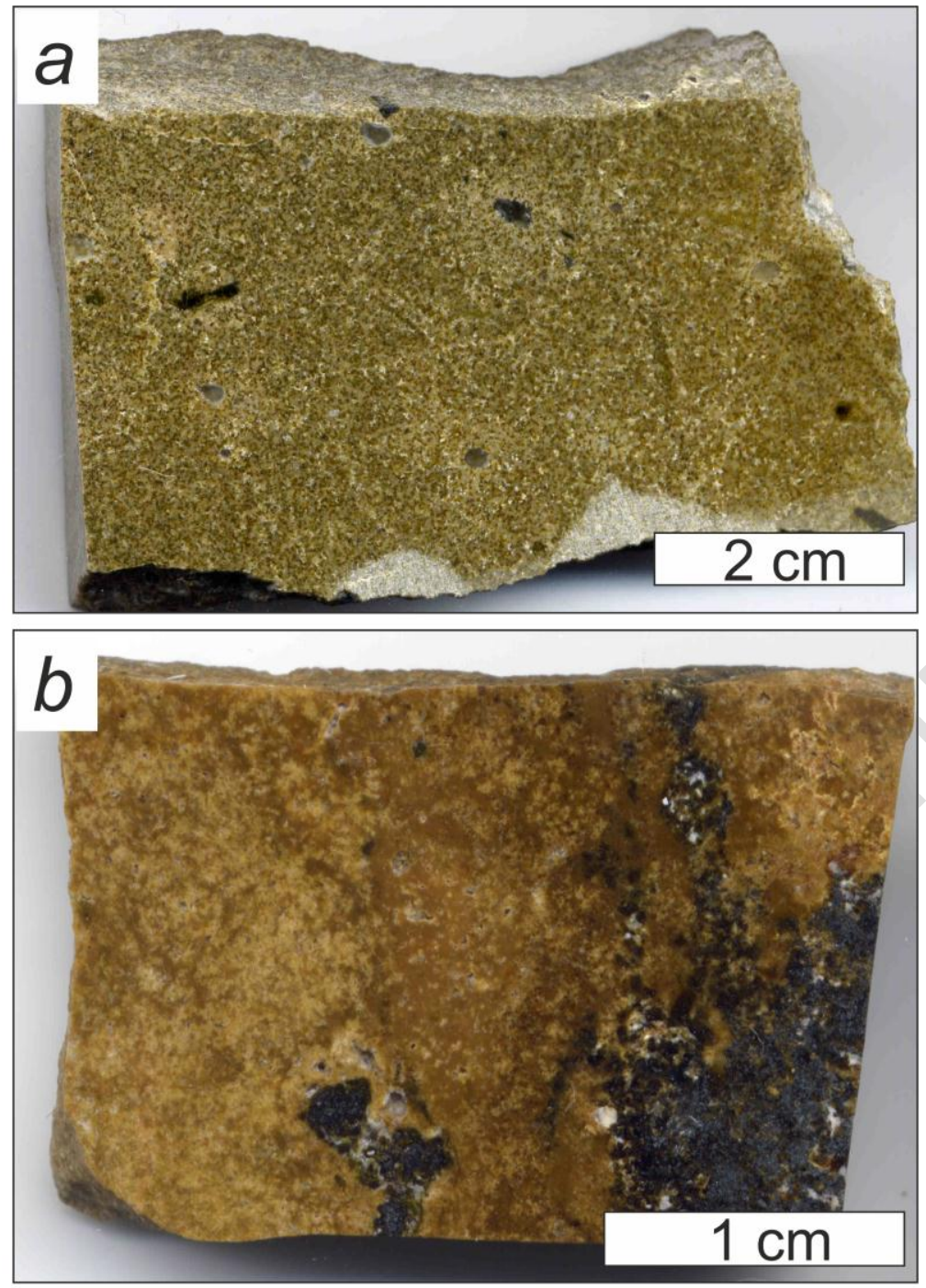

\section{Figure 1}

Fig. 1. (a) Fine-grained wollastonite-gehlenite-andradite-esseneite hornfels (ZPP12) with rare amygdules filled with zeolite-like minerals, ettringite and rarer leucite, where levantite is a rockforming mineral. (b) Porous esseneite-gehlenite-wollastonite-andradite rock (GZ12) with areas enriched in hematite and relatively large levantite, esseneite, gehlenite and andradite crystals (dark area). 

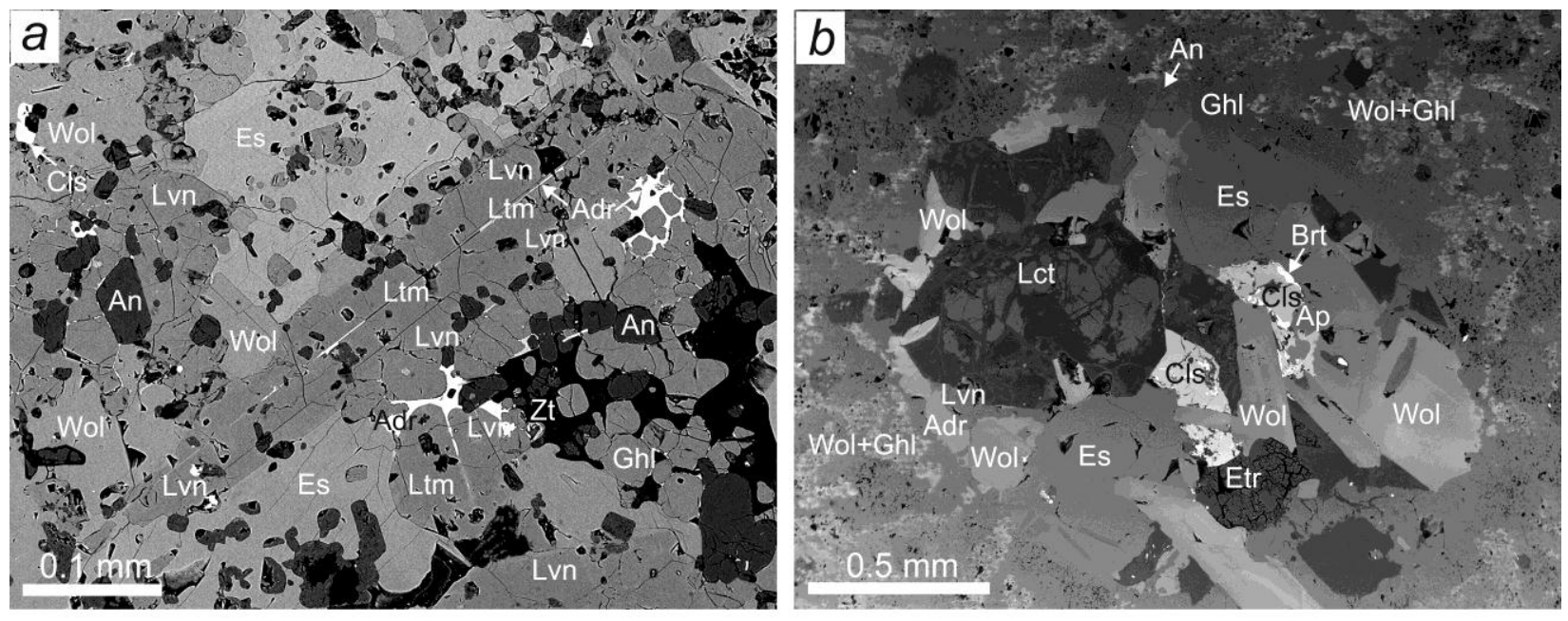

Figure 2

Fig. 2. Fine-grained rock (ZPP12), where levantite is widespread and usually forms later zones on long-prismatic crystals of the latiumite-levantite series minerals ( 50/50) up to $0.6 \mathrm{~mm}$ in length. (a) Twinning crystal of latiumite-levantite with thin inclusion of garnet on the twinning boundary, BSE image. (b) Aggregate of relatively large crystals of partially altered leucite, wollastonite, celsian and esseneite, BSE image. Levantite in these aggregates is rare and contains less than $30-35 \%$ of latiumite end-member.

$\mathrm{Adr}=$ schorlomite-andradite, $\mathrm{An}=$ anorthite, $\mathrm{Ap}=$ fluorapatite, $\mathrm{Brt}=$ baryte, $\mathrm{Cls}=$ celsian, Es $=$ esseneite, $\mathrm{Etr}=$ ettringite-thaumasite, $\mathrm{Ghl}=$ gehlenite, $\mathrm{Lct}=$ leucite, $\mathrm{Ltm}=$ latiumite, $\mathrm{Lvn}=$ levantite, $\mathrm{Wol}=$ wollastonite, $\mathrm{Zt}=\mathrm{K}$-bearing zeolite. 

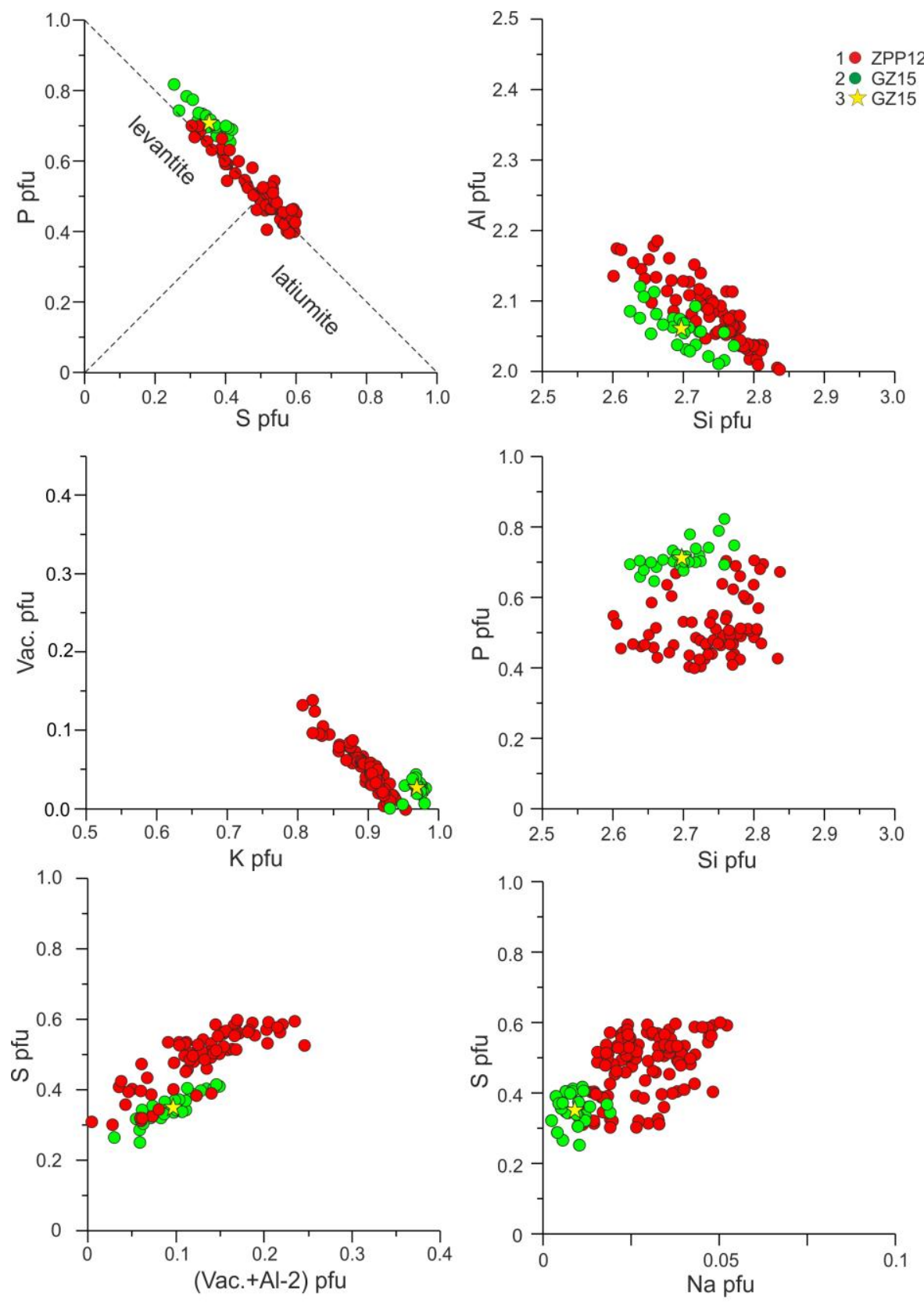

Figure 3

Fig. 3. Microprobe analyses data on the latiumite-levantite mineral series in diagrams: $\mathrm{P}$ pfu $-\mathrm{S}$ pfu (some points of microprobe analyses are located above the $\mathrm{P}+\mathrm{S}=1$ line because of a small quantities of the $\mathrm{P}$ that enters to the terahedrons of double layers); $\mathrm{Al}$ pfu - Si pfu; Vac. pfu - K pfu (vacancies (Vac.) were calculated as $4-(\mathrm{K}+\mathrm{Ca}+\mathrm{Na}+\mathrm{Mg}+\mathrm{Ba})$; P pfu $-\mathrm{Si} \mathrm{pfu}$; S pfu - Vac. + Al-2 pfu; S pfu - Na pfu. 


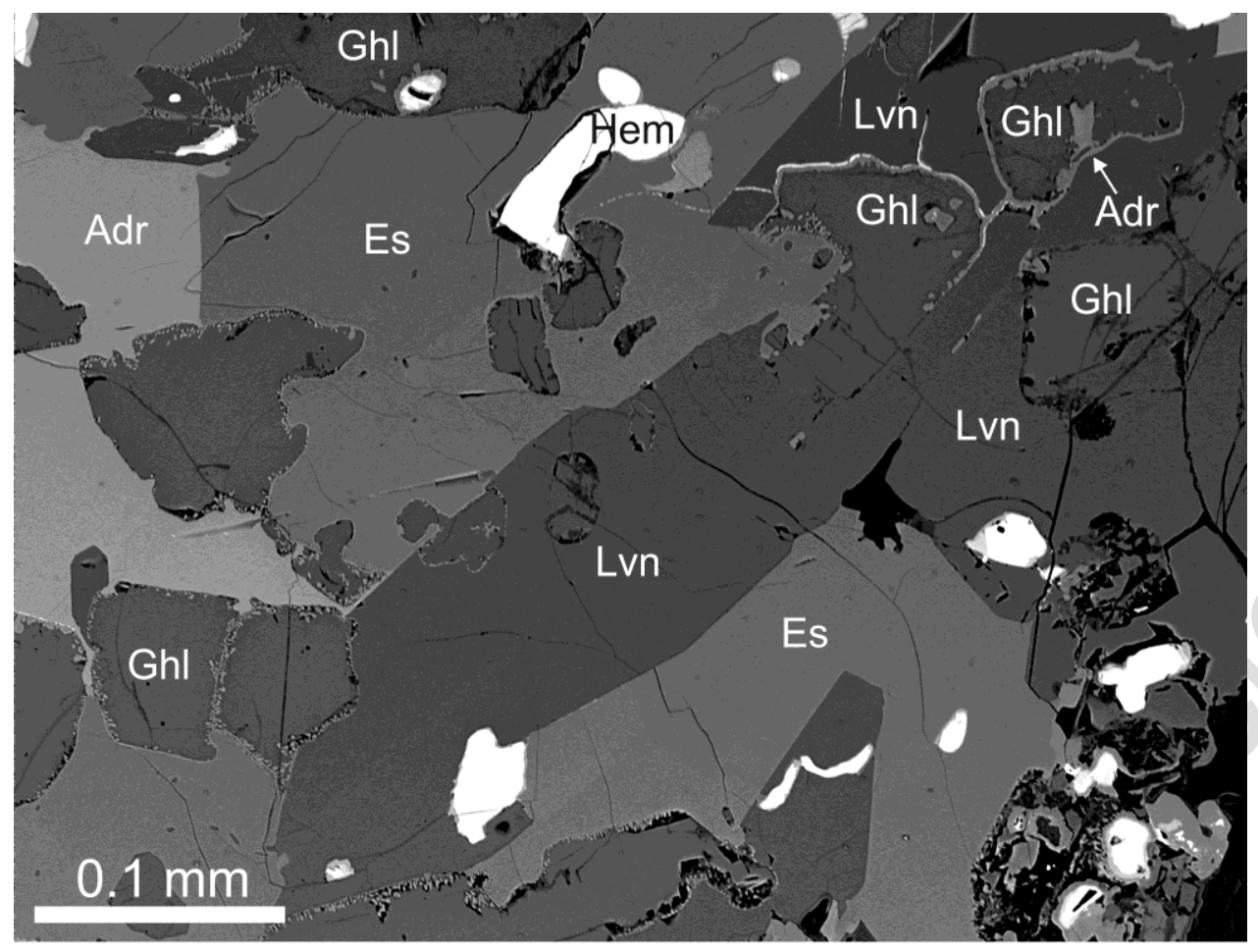

Figure 4

Fig. 4. Relatively homogenous levantite crystal in esseneite-wollastonite-anorthite paralava (boulder from wadi Bokek near Mt. Parsa, GZ15), which was used for microprobe measurements, structural and optical investigation (Table 1, analysis 3). Gehlenite has andradite reaction rims. BSE image.

Lvn $=$ levantite, $\mathrm{Wol}=$ wollastonite, $\mathrm{Ghl}=$ gehlenite, $\mathrm{Adr}=$ schorlomite-andradite, $\mathrm{An}=$ anorthite, Hem = hematite, Es =esseneite. 


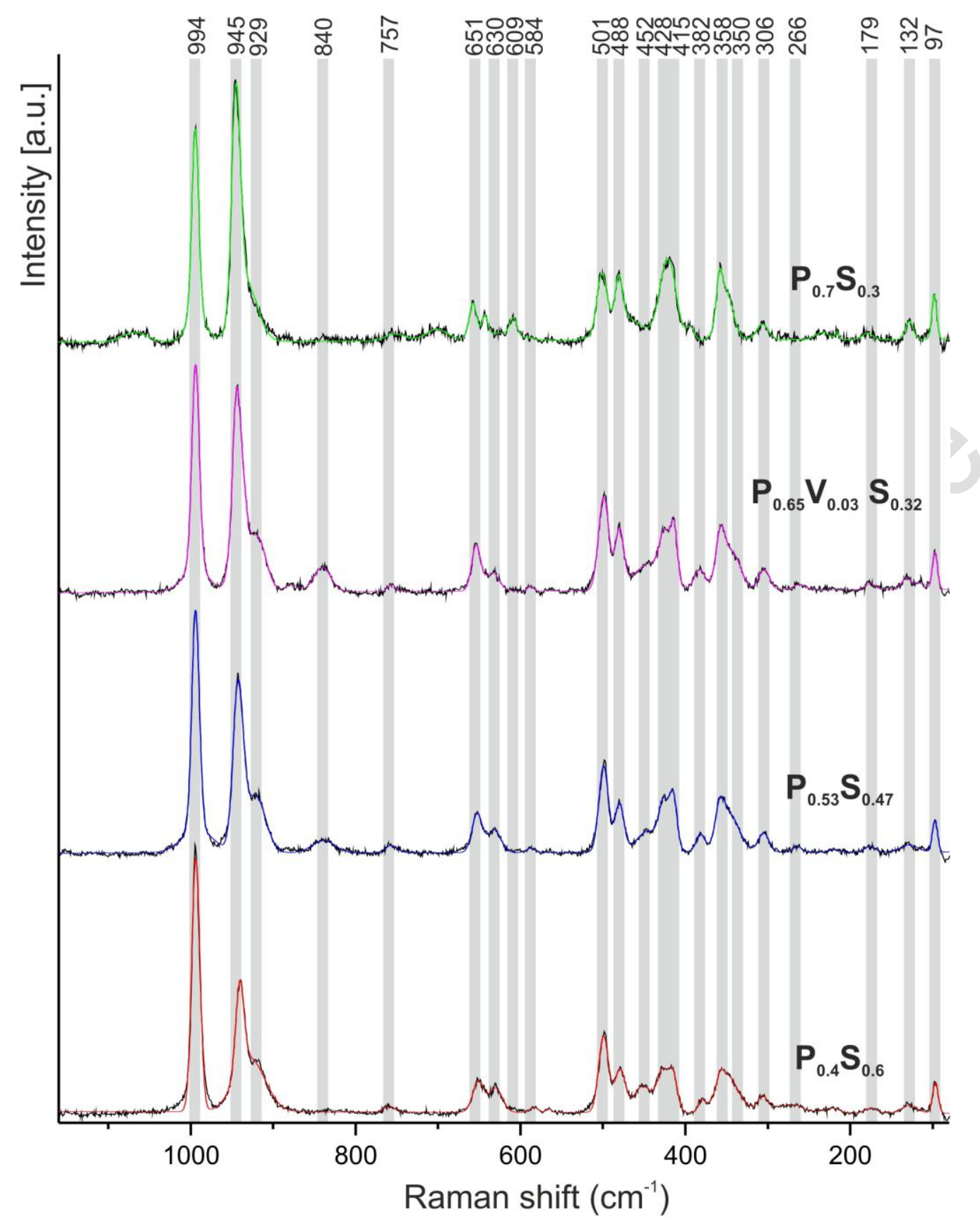

Figure 5

Fig. 5. Raman spectra of minerals of the levantite-latiumite series with differentt $\mathrm{P} / \mathrm{S}$ ratio. 


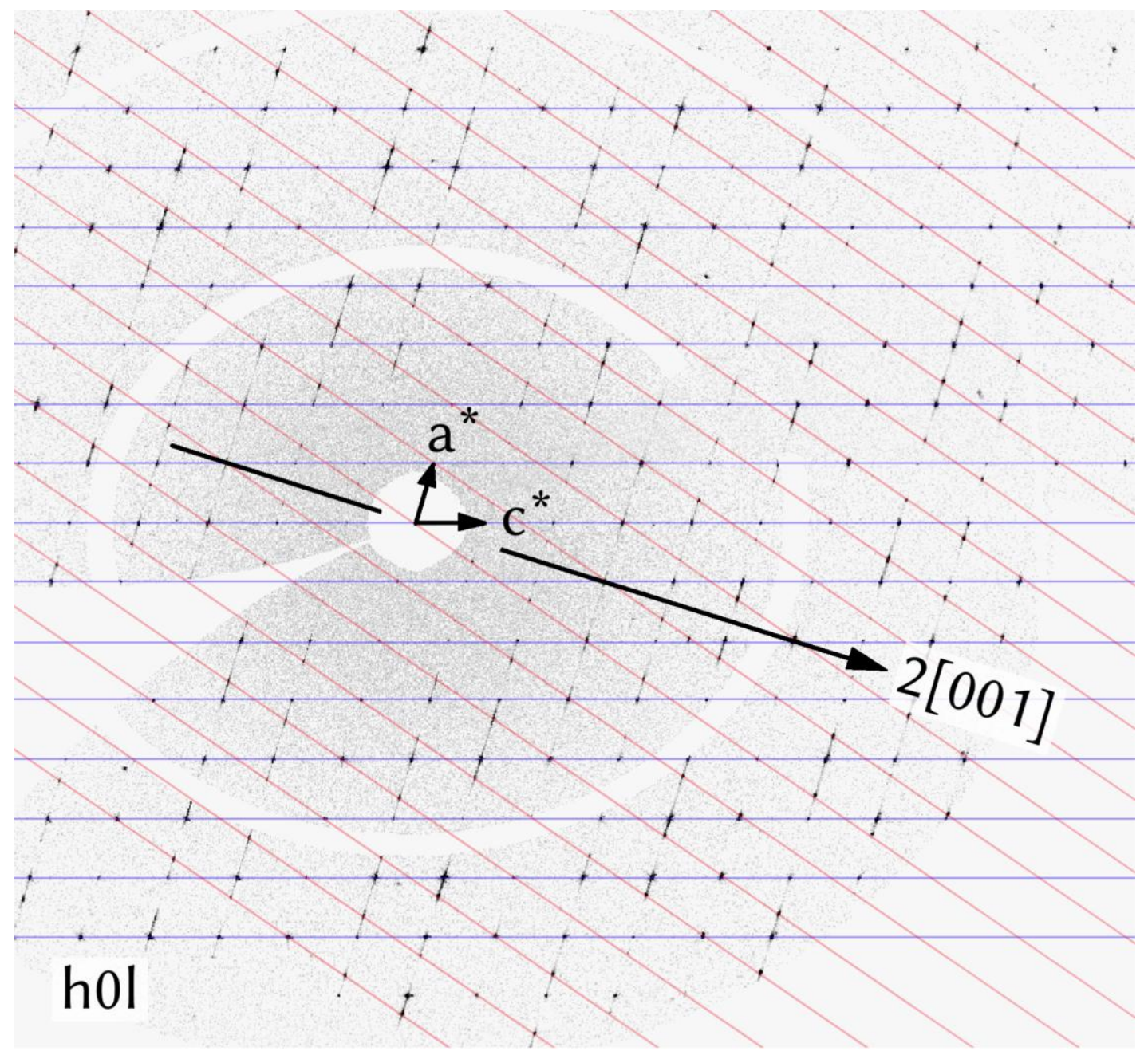

Figure 6

Fig. 6. Reciprocal space layer $h 0 l$. The red lattice is generated by the 2[001]-twinning and exhibits almost perfect overlap at lattice nodes with $l=3 n$. One-dimensional diffuse scattering parallel to $\boldsymbol{a}^{*}$ is present. 

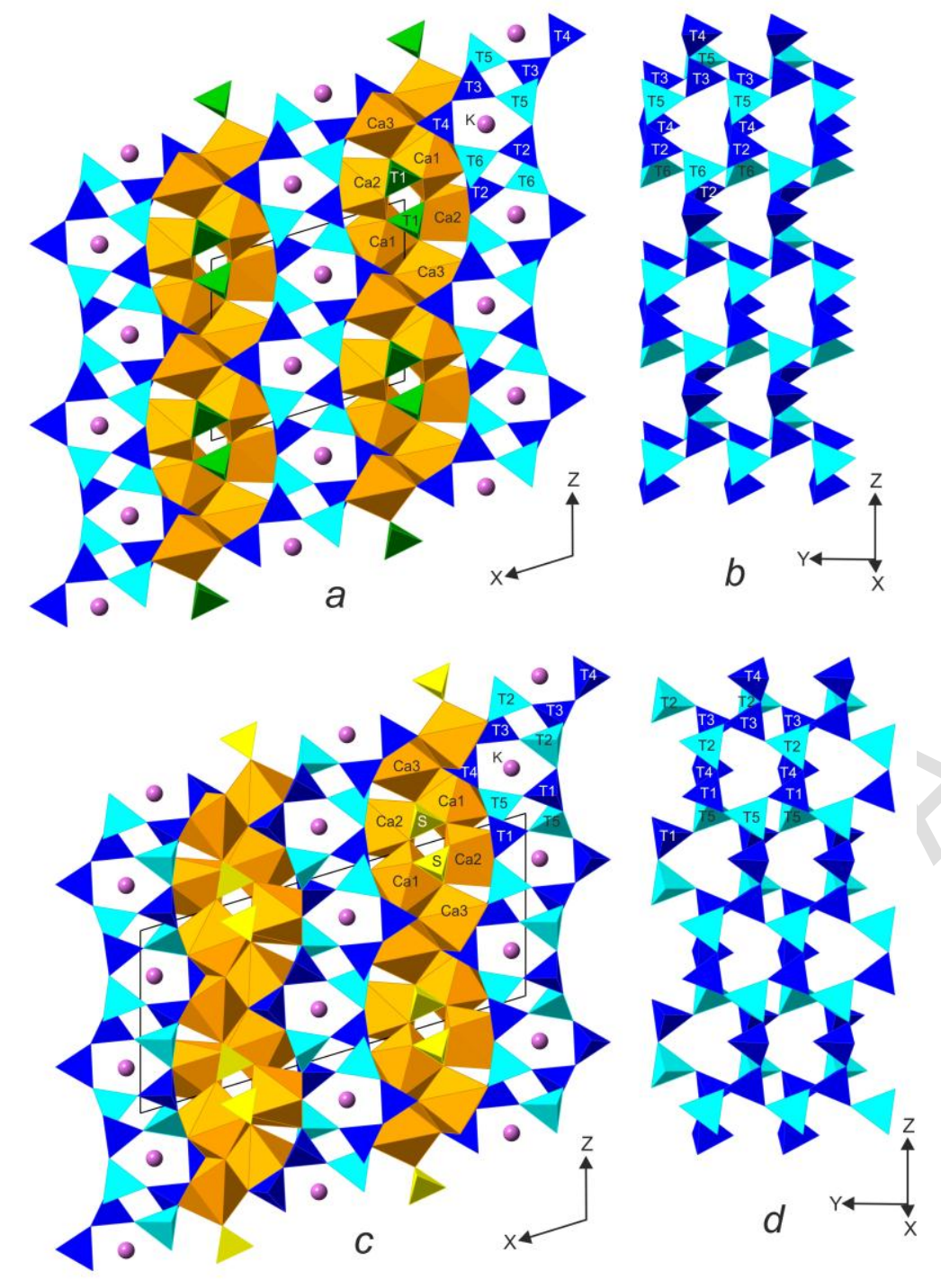

Figure 7

Fig. 7. Levantite structure $(a, b)$ compaired to tuscanite structure $(c, d)$.

$(a, c)$ projection on $(010) ;(b, d)$ projection of separate tetrahedral zweier double layer on (100).

Tuscanite polyhedra are named like by Mellini and Merlino (1977). The main cation in tetrahedra are: $\mathrm{P}$ is in green, $\mathrm{S}$ in yellow, $\mathrm{Si}$ in dark blue and $\mathrm{Al}$ in blue. 